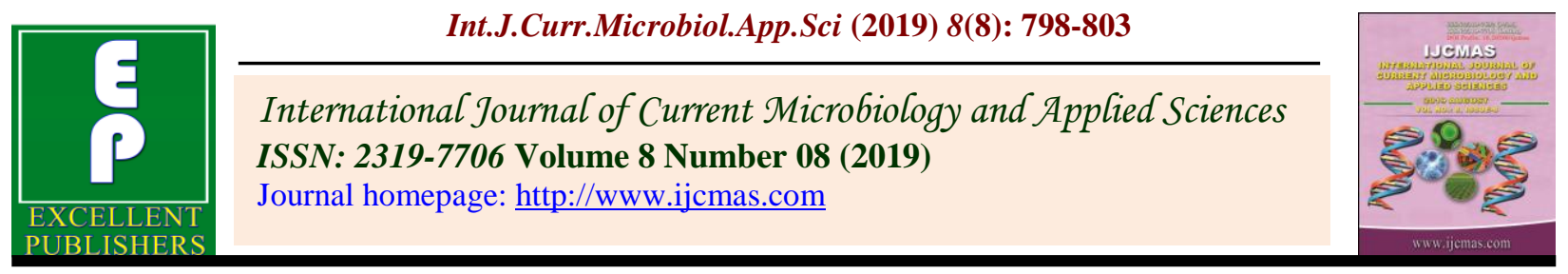

Original Research Article https://doi.org/10.20546/ijcmas.2019.808.090

\title{
Evaluation of Sowing Time for Kharif Pigeonpea and Validation by Infocrop
}

\author{
Deepak Kumar*, A.R. Tupe, Subhradip Bhattacharjee, \\ Pramod Kumar and Sheilendra Kumar
}

\begin{abstract}
Department of Agronomy, Panjabrao Deshmukh Krishi Vidyapeeth, Akola
(Maharashtra), India

*Corresponding author
\end{abstract}

Keywords

Pigeon pea, Kharif, Validation, Infocrop

Article Info

Accepted:

07 July 2019

Available Online:

10 August 2019

\section{A B S T R A C T}

A field experiment was conducted during kharif season of 2016-17to identify optimum meteorological week for sowing of pigeonpea. The treatments were four sowing dates $\left(26^{\text {th }}\right.$ MW-30 June, $28^{\text {th }}$ MW-15 June, $31^{\text {th }}$ MW-30 July and $33^{\text {th }}$ MW-15 August and three varieties (Asha (ICPL87119), PKV-TARA, BSMR-736) with three replications and twelve treatment combinations were tested in Factorial Randomized Block Design. The results revealed that the Pigeonpea variety PKV-TARA recorded significantly higher grain $\left(2182 \mathrm{~kg} \mathrm{ha}^{-1}\right)$. Yield contributing characters such as number of pods plant ${ }^{-1}(184)$, straw yield $\left(6356 \mathrm{~kg} \mathrm{ha}^{-1}\right)$ and biological yield $\left(8537 \mathrm{~kg} \mathrm{ha}^{-1}\right)$ were higher in variety PKV-TARA than followed by Asha and BSMR-736. The performance of Crop simulation model (InfoCrop model $\mathrm{v}$ beta) in respect of phenological events (Days to flowering, days to maturity) was found to be highly reliable. Day to flowering and biological yield was well matched with model. Grain yield and straw yield were found to be slightly overestimated by model.

\section{Introduction}

Pigeonpea [Cajanus cajan (L.) Millsp] exploited leguminous crop belongs to family Fabaceae. It is also known as arhar, tur or red gram. The pigeonpea is a perennial legume, fast growing, deep extensive rooted system with large food reserves helps the plants to survive under unfavorable condition such as drought. Pigeonpea is an annual or a perennial shrub cultivated throughout India and it's normally grown in India as rainfed crop in rainy season. India is deficit both in pulses and oilseeds production. In India this crop is grown for dal purpose. Pigeonpea is grown in India both a food crop (dried peas or green vegetables peas) and a forage/cover crop.

Maharashtra is the largest producer of pigeonpea, accounting for over $30 \%$ of total production in the country followed by Karnataka, Madhya Pradesh and Andhra 
Pradesh with $17 \%, 13 \%$ and $8 \%$ respectively. The total Indian pulses production is 17.5 million tonns in 2015-16. The average annual consumption of pulses in India is estimated to be 23-24 million tonns. Pigeonpea is grown in some of the African countries owing to their suitable climatic condition. The total production pigeonpea in India accounts for about $65 \%$ of the total global output. (Source: FAO statistics 2015). The pigeonpea crop suffers more in the condition of delayed sowing (Padhi, 1995).

The crop growth models can be used to predict crop performance in a given region, where the crop has not been grown before or not grown under optimal conditions. It can be developed at various levels of complexity. The level of complexity required depends on the objective of the modeling exercise.

The InfoCrop is generic crop growth model that can simulate the effects of weather, soil, agronomic management practices (including planting, nitrogen, residue and irrigation) and major pests on crop growth and yield. The InfoCrop are considered different crop development and growth process, which influence the crop yield. It performs well in tropical agro environments. The InfoCrop requires weather data, edaphic data, varietal data, crop data, insect and pest data output from the InfoCrop is like yield, total dry matter, crop duration, evapotranspiration, $\mathrm{N}$ uptake, greenhouse gas emissions and soil C, $\mathrm{N}$ and water dynamics.(Mote et. al.2016). The InfoCrop consider the process like crop growth, crop pest interactions, soil water balance, soil nitrogen balance, soil organic carbon dynamics and emission of greenhouse gases.

The study will be helpful to weather parameters plays an important role at different phenophase of the pigeonpea influencing the growth and final yield performance. Sowing at different times create a different set of environment conditions, which results in variation in yield of the same varieties. It will be beneficial for farmer and also the research worker to carry out the research on pigeonpea under adverse environmental conditions.

\section{Materials and Methods}

The experiment was carried out at farm in the field number 88, AICRP on Weed management. Dr. Panjabrao Deshmukh Krishi Vidyapeeth, Akola during kharif 2016-2017 in factorial randomized block design with twelve treatments replicated thrice. The treatments under study were sowing in different meteorological week's viz. $\mathrm{D}_{1}$ (26 MW (30 June), $\mathrm{D}_{2} 28 \mathrm{MW}$ (15 July), $\mathrm{D}_{3} 31 \mathrm{MW}$ (30 July) and $\mathrm{D}_{4} 33 \mathrm{MW}$ (15 August) with three varieties viz $\mathrm{V}_{1}$ Asha (ICPL- 87119), $\mathrm{V}_{2}$ PKVTARA and $\mathrm{V}_{3}$ BSMR-736.

The experimental field was laid out in thirty six unit plots each of $17.01 \mathrm{~m}^{2}(4.20 \times 4.05 \mathrm{~m})$ gross and $11.25 \mathrm{~m}^{2}(3.00 \times 3.75 \mathrm{~m})$ net size. A distance of $2 \mathrm{~m}$ was kept between the plots.

The soil of the experimental field was vertisols (medium black) clayey in texture. The recommended dose of fertilizer $(25 \mathrm{~kg} \mathrm{~N}$ $+50 \mathrm{~kg} \mathrm{P}+00 \mathrm{~kg} \mathrm{~K} \mathrm{~K}_{2} \mathrm{O} / \mathrm{ha}$ ) and all the recommended agronomic practices were adapted during the experimental period.

The various phenological characters viz. Days to flowering, Days to maturity, Leaf area index were recorded. Grain yield, straw yield and biomass, were recorded at the time of harvest.

\section{Results and Discussion}

The observed and simulated days to flowering, day to maturity, leaf area index of pigeonpea varieties under four sowing times are presented in Table 1. 


\section{Days to flowering}

The Asha variety took 117 days for flowering and the InfoCrop model simulated days to flowering are 123 days. Pigeonpea is a short day plant. The day length starts declining from July onwards in northern hemisphere with steeper fall from October onwards by Reddy et al., (2015). With delay in sowing, flowering was induced earlier resulting in less vegetative growth and earliness in maturity resulting in low grain yield. The difference between the simulated and observed days for flowering is 6 days and the deviation from observed data shown as error \% is 5 .

The similar result was found by BSMR-736 variety took 111 days for flowering and the InfoCrop model simulated days to flowering is 121 days. The difference between the simulated and observed days for flowering is 10 days and the deviation from observed data shown as error \% is 9 .

\section{Days to maturity}

The observed and simulated days to maturity of pigeonpea variety under four dates of sowing are presented in Table 1.

Results showed that variety Asha took 175 days for maturity being early with delay in sowing. The InfoCrop model simulated days to maturity between 182 days under four sowing times. The difference between simulated and observed value was 7 days and the deviation indicated overestimation with mean value of $4 \%$.

Similar results showed that PKV-TARA took 170 days for maturity and the InfoCrop model also simulated days to maturity was 177 days. The difference between the simulated and observed days for maturity was 7 days and the deviation from observed data shown as error $4 \%$.
Similar results were obtained for variety BSMR-736 model simulated days to maturity between 178 days against the observed values of 170 days under four dates of sowing. The difference between simulated and observed value was 8 days and the deviation indicated overestimation with mean value of $5 \%$.

The result revealed that model under estimated days to maturity under $\mathrm{D}_{1}(26 \mathrm{MW}), \mathrm{D}_{2}(28$ $\mathrm{MW})$ and $\mathrm{D}_{3}(31 \mathrm{MW})$ and $\mathrm{D}_{4}(33 \mathrm{MW})$. The difference between simulated and observed value was underestimation with mean value of 13 and the deviation indicated under estimation with mean value was $7 \%$ which was less than $10 \%$. Thus, simulated values were similar with observed value.

\section{Leaf area index}

The observed maximum leaf area index of pigeonpea for variety PKV-TARA varied between 3.26. InfoCrop model simulated values varied between 3.37. InfoCrop model simulated values were close to observed leaf area index with slightly underestimation the percent error of 3 states the suitability of model in simulating leaf area index.

In case of variety Asha the model simulated maximum leaf area index of 3.28 under four dates of sowing against the observed maximum leaf area index of 3.21. The InfoCrop model was found to underestimate the maximum leaf area index for variety Asha. The percent error of $2 \%$ states the suitability of model in simulating leaf area index.

Similar results were obtained for variety BSMR-736 the model simulated maximum leaf area index of 3.16 under four sowing times against the observed maximum leaf area index of 3.01. The InfoCrop model was found to underestimate the maximum leaf area index for variety BSMR-736. The percent error is $4 \%$. 
Table.1 Simulated and observed phenology, growth contributing characters of Pigeonpea

\begin{tabular}{|c|c|c|c|c|c|c|c|c|c|c|c|c|}
\hline \multirow[t]{3}{*}{ Treatments } & \multicolumn{8}{|c|}{ Phenology } & \multirow{2}{*}{\multicolumn{4}{|c|}{$\begin{array}{c}\text { Growth } \\
\text { LAI }\end{array}$}} \\
\hline & \multicolumn{4}{|c|}{ Days to flowering } & \multicolumn{4}{|c|}{ Days to maturity } & & & & \\
\hline & $\mathbf{S}$ & $\mathbf{O}$ & D & $\% \mathrm{E}$ & $\mathbf{S}$ & $\mathbf{O}$ & D & $\% \mathrm{E}$ & $\mathbf{S}$ & $\mathbf{O}$ & D & $\% \mathrm{E}$ \\
\hline \multicolumn{13}{|l|}{ Sowing times (D) } \\
\hline $\mathrm{D}_{1}(26 \mathrm{MW})$ & 140 & 129 & 11 & 8 & 219 & 193 & 26 & 13 & 3.43 & 3.31 & 0.12 & 3 \\
\hline $\mathrm{D}_{2}(28 \mathrm{MW})$ & 138 & 126 & 12 & 9 & 206 & 192 & 14 & 7 & 2.97 & 3.20 & -0.23 & -7 \\
\hline $\mathrm{D}_{3}(31 \mathrm{MW})$ & 122 & 114 & 8 & 7 & 180 & 176 & 4 & 2 & 2.80 & 3.10 & -0.30 & -9 \\
\hline $\mathrm{D}_{4}(33 \mathrm{MW})$ & 113 & 108 & 5 & 4 & 177 & 168 & 9 & 5 & 2.73 & 3.04 & -0.31 & -10 \\
\hline Mean & 128 & 119 & 9 & 7 & 195 & 182 & 13 & 7 & 2.98 & 3.16 & -0.18 & -5 \\
\hline \multicolumn{13}{|l|}{ Varieties (V) } \\
\hline$V_{1}$ (Asha) & 123 & 117 & 6 & 5 & 182 & 175 & 7 & 4 & 3.28 & 3.21 & 0.07 & 2 \\
\hline $\mathbf{V}_{2}($ PKV-TARA) & 116 & 109 & 7 & 6 & 177 & 170 & 7 & 4 & 3.37 & 3.26 & 0.11 & 3 \\
\hline V & 121 & 111 & 10 & 9 & 178 & 170 & 8 & 5 & 3.16 & 3.01 & 0.15 & 4 \\
\hline Mean & 120 & 112 & 8 & 7 & 179 & 171 & 7 & 4 & 3.27 & 3.16 & 0.11 & 3 \\
\hline
\end{tabular}

Table.2 Simulated and observed yield contributing characters of Pigeonpea

\begin{tabular}{|c|c|c|c|c|c|c|c|c|c|c|c|c|}
\hline \multirow[t]{3}{*}{ Treatments } & \multicolumn{12}{|c|}{ Yield } \\
\hline & \multicolumn{4}{|c|}{ Grain yield $\left(\mathrm{kg} \mathrm{ha}^{-1}\right)$} & \multicolumn{4}{|c|}{ Straw yield $\left(\mathrm{kg} \mathrm{ha}^{-1}\right)$} & \multicolumn{4}{|c|}{ Biomass $\left(\mathrm{kg} \mathrm{ha}^{-1}\right)$} \\
\hline & $\mathbf{S}$ & $\mathbf{0}$ & D & $\% \mathrm{E}$ & $\mathbf{S}$ & $\mathbf{0}$ & D & $\% \mathbf{E}$ & $\mathbf{S}$ & $\mathbf{O}$ & D & $\% \mathbf{E}$ \\
\hline \multicolumn{13}{|c|}{ Sowing times (D) } \\
\hline$D_{1}(26 \mathrm{MW})$ & 2531 & 2146 & 385 & 17 & 6043 & 6862 & -819 & -11 & 8974 & 9009 & -35 & -0.3 \\
\hline $\mathrm{D}_{2}(28 \mathrm{MW})$ & 2315 & 2114 & 201 & 9 & 5802 & 6469 & -667 & -10 & 8117 & 8583 & -466 & -5 \\
\hline $\mathrm{D}_{3}(31 \mathrm{MW})$ & 2117 & 2049 & 68 & 3 & 5626 & 5971 & -345 & -5 & 7743 & 8020 & -277 & -3 \\
\hline $\mathrm{D}_{4}(33 \mathrm{MW})$ & 2075 & 1969 & 106 & 5 & 5382 & 5354 & 28 & 0.5 & 7257 & 7324 & -67 & -0.8 \\
\hline Mean & 2259 & 2069 & 190 & 8 & 5713 & 6164 & -451 & -6 & 8023 & 8234 & -211 & -2.1 \\
\hline \multicolumn{13}{|l|}{ Varieties (V) } \\
\hline$V_{1}$ (Asha) & 2271 & 2082 & 189 & 9 & 5547 & 6135 & -588 & -9 & 7818 & 8217 & -399 & -4 \\
\hline $\begin{array}{l}\text { V }_{2}(\text { PKV- } \\
\text { TARA) }\end{array}$ & 2405 & 2182 & 223 & 10 & 6275 & 6356 & -81 & -1 & 8980 & 8537 & 443 & 5 \\
\hline $\begin{array}{l}V_{3}(B S M R \\
-736)\end{array}$ & 1953 & 1945 & 8 & 0.5 & 5318 & 6002 & -684 & -11 & 7271 & 7947 & -676 & -8 \\
\hline Mean & 2209 & 2069 & 140 & 6 & 5713 & 6164 & -451 & -7 & 8023 & 8234 & -211 & -2.3 \\
\hline $\begin{array}{l}\mathrm{S}=\text { Model } \\
\mathrm{D}=(\mathrm{P}-\mathrm{O})\end{array}$ & & & & & lue & & & & & & & \\
\hline
\end{tabular}

The result revealed that model under estimated of maximum leaf area index under $\mathrm{D}_{1}(26 \mathrm{MW}), \mathrm{D}_{2}(28 \mathrm{MW}), \mathrm{D}_{3}(31 \mathrm{MW})$ and $\mathrm{D}_{4} \quad(33 \mathrm{MW})$. The difference between simulated and observed value was underestimation with mean value of -0.18 and the deviation indicated under estimation with mean value was $-5 \%$ which was less than $10 \%$. Thus, simulated values were well matching with observed value. The observed 
and simulated grain yield, straw yield and biomass of pigeonpea varieties under four sowing times are presented in Table 1.

\section{Grain yield $\left(\mathrm{kg} \mathrm{ha}^{-1}\right)$}

It may be seen that the observed grain yield for variety PKV-TARA was $2182 \mathrm{~kg} \mathrm{ha}^{-1}$ and the simulated grain yield was $2405 \mathrm{~kg} \mathrm{ha}^{-1}$. The difference between the simulated and the observed value was 223 and the percent error was $10 \%$.Similarly, for variety Asha the observed grain yield was $2082 \mathrm{ha}^{-1}$ and the simulated grain yield was $2271 \mathrm{ha}^{-1}$. The difference between the simulated and the observed value was 189 and the percent error was $9 \%$. Meanwhile the variety BSMR-736 the observed grain yield was $1945 \mathrm{ha}^{-1}$ and the simulated grain yield was $1953 \mathrm{ha}^{-1}$. The difference between the simulated and the observed value was 8 and the percent error was $0.41 \%$ (Table 2).

The observed grain yield varied between 2146 $\mathrm{kg} \mathrm{ha}^{-1}\left(\mathrm{D}_{1}\right), 2114 \mathrm{~kg} / \mathrm{ha}\left(\mathrm{D}_{2}\right), 2049 \mathrm{~kg} \mathrm{ha}^{-1}$ $\left(D_{3}\right)$ and $1969 \mathrm{~kg} \mathrm{ha}^{-1}\left(\mathrm{D}_{4}\right)$ against the simulated yield ranging from 2531, 2315, $2117,2075 \mathrm{~kg} \mathrm{ha}^{-1}$ and the difference between observed and the simulated value was 385 , 201, 68, 106 and the percent error was $17 \%$, $9 \%, 3 \%$ and $5 \%$ respectively. The mean deviation value was 8.5 , which was less than $10 \%$. Thus, simulated values were well matching with observed value but the $\left(D_{1}\right)$ percent error was $17 \%$ higher than $10 \%$, thus, simulated values were not matching with observed value.

\section{Straw yield $\left(\mathrm{kg} \mathrm{ha}^{-1}\right)$}

The observed straw yield for variety PKVTARA was $6356 \mathrm{~kg} \mathrm{ha}^{-1}$ and the simulated straw yield was $6275 \mathrm{~kg} \mathrm{ha}^{-1}$ the difference between the simulated and the observed value was -81 and the percent error was $-1 \%$. Similarly for variety Asha the observed straw yield was $6135 \mathrm{~kg} \mathrm{ha}^{-1}$ and the simulated straw yield was $5547 \mathrm{~kg} \mathrm{ha}^{-1}$. The difference between the simulated and the observed value was -588 and the percent error was $-9 \%$. More over the variety BSMR-736 the observed straw yield was $6002 \mathrm{~kg} \mathrm{ha}^{-1}$ and the simulated straw yield was $5318 \mathrm{~kg} \mathrm{ha}^{-1}$. The difference between the simulated and the observed value was -684 and the percent error was $-11 \%$.

The observed straw yield varied between $6862 \mathrm{~kg} \mathrm{ha}^{-1}\left(\mathrm{D}_{1}\right), 6469 \mathrm{~kg} \mathrm{ha}^{-1}\left(\mathrm{D}_{2}\right), 5971 \mathrm{~kg}$ $\mathrm{ha}^{-1}\left(\mathrm{D}_{3}\right)$ and $5354 \mathrm{~kg} \mathrm{ha}^{-1}\left(\mathrm{D}_{4}\right)$ against the simulated yield ranging from 6043, 5802, $5626,5382 \mathrm{~kg} \mathrm{ha}^{-1}$ and the difference between observed and the simulated value was -819 , $667,-345,28$ and the percent error was $-11 \%$, $-10 \%,-5 \%, 0.52 \%$ respectively. The mean deviation value was $-6.37 \%$ which was less than $10 \%$. Thus, simulated values were well matching with observed value.

\section{Biomass yield $\mathrm{kg} \mathrm{ha}^{-1}$}

The observed biomass yield for variety PKVTARA was 8537 and the simulated biomass yield was 8980 . The difference between the simulated and the observed value was 443 and the percent error was 5.Similarly for variety Asha the observed biomass yield was $8217 \mathrm{~kg}$ $\mathrm{ha}^{-1}$ and the simulated biomass yield was $7818 \mathrm{~kg} \mathrm{ha}^{-1}$. The difference between the simulated and the observed value was -399 and the percent error was -4.Similarly for variety BSMR-736 the observed biomass yield was $7947 \mathrm{~kg} \mathrm{ha}^{-1}$ and the simulated biomass yield was $7271 \mathrm{~kg} \mathrm{ha}{ }^{-1}$.The difference between the simulated and the observed value was -676 and the percent error was -8 .

The observed biomass yield varied between $9009 \mathrm{~kg} \mathrm{ha}^{-1}\left(\mathrm{D}_{1}\right), 8583 \mathrm{~kg} \mathrm{ha}^{-1}\left(\mathrm{D}_{2}\right), 8020 \mathrm{~kg}$ $\mathrm{ha}^{-1}\left(\mathrm{D}_{3}\right)$ and $7324 \mathrm{~kg} \mathrm{ha}^{-1}\left(\mathrm{D}_{4}\right)$ against the simulated yield ranging from 8974, 8117, 
$7743,7257 \mathrm{~kg} \mathrm{ha}^{-1}$ and the difference between observed and the simulated value was -35 , $466,-277,-67$ and the percent error was $0.38 \%,-5 \%,-3 \%,-0.83 \%$ respectively. The mean deviation value was -2.19 , which was less than $10 \%$. Thus, simulated values were well matching with observed value.

\section{Crop simulation modeling}

Crop simulation model (InfoCrop $\mathrm{v}$ beta) performance in respect of phenological phases was found to be highly reliable. Day to flowering, days to maturity, Leaf area index, seed yield and biological yield was found to be underestimated by model for all three varieties except straw yield that is overestimated.

The pigeonpea variety PKV-TARA found most suitable for higher grain yield where sowing at $\mathrm{D}_{1}(26 \mathrm{MW})$ as compare to other varieties.

Grain yield, straw yield, biomass, days to flowering, days to maturity, leaf area index were satisfactory simulated by InfoCrop model, however straw yield was overestimated for all three varieties and rest at the parameters was underestimated by the model with reasonable agreement. This shows the robustness at InfoCrop model: proper calibration at InfoCrop model works well for yield simulation during projected period. By and large the model performance was found good during kharif season for pigeonpea crop at Akola location.

\section{References}

Anonymous (2013). Food and Agricultural Organization.

Mote, B. M., M. J. Vasani, H. K. Ahir, S. B. Yadav and V. Pandey (2016). "Simulation of Phenology and Yield Attributing Characters of Legume Crops Using DSSAT and InfoCrop Model." Advances in Life Sciences 5(13): 5265527.

Padhi, A.K. (1995). "Effect of sowing date and planting geometry on yield of redgram (Cajanus cajan) genotypes". Indian J. Agron., 40(1): 72-76.

Reddy, G. K., P. M. Reddy, P. L. Kumari and T. G. Krishna (2015). "Response of pigeonpea varieties to time of sowing during rabi season" Journal of Agriculture and Veterinary Science Volume 8, Issue 2 Ver. II PP 12-15.

\section{How to cite this article:}

Deepak Kumar, A.R. Tupe, Subhradip Bhattacharjee, Pramod Kumar and Sheilendra Kumar. 2019. Evaluation of Sowing Time for Kharif Pigeonpea and Validation by Infocrop. Int.J.Curr.Microbiol.App.Sci. 8(08): 798-803. doi: https://doi.org/10.20546/ijcmas.2019.808.090 